\title{
Microcredit Impacts: Evidence from a Large-Scale Observational Study in Brazil
}

\author{
Rafael Goldszmidt ${ }^{1}$. Patrick Behr ${ }^{2}$. Cesar Zucco ${ }^{1}$. Anna-Katharina Lenz ${ }^{2}$. \\ Lauro Gonzalez ${ }^{3} \cdot$ Martin Valdivia $^{4}$
}

Accepted: 12 July 2021 / Published online: 23 August 2021

(c) The Author(s) 2021

\begin{abstract}
This paper studies the impact of microcredit in Brazil. We use a propensity score matching on original primary data on business and personal outcomes to compare veteran clients of BNDES-Brazil's largest government-owned development bank-to a matched sample of more recent clients. Based on administrative data as well as data from a survey of 2107 clients from the South and Northeast regions of Brazil, the findings show no significant impacts on income, employment generation, access to credit, and business formalization, except for the poorest Municipalities of the Northeast, where microcredit presented positive effects.
\end{abstract}

Keywords Brazil · Gender · Impact study $\cdot$ Microcredit · Propensity score matching

\section{Résumé}

Cet article étudie l'impact du microcrédit au Brésil. Nous utilisons la méthode d'appariemment sur score de propension sur des données primaires originales issues de résultats commerciaux et personnels pour comparer les clients de longue date de la BNDES - la plus grande banque de développement appartenant au gouvernement du Brésil-à un échantillon apparié de clients plus récents. Sur la base de données administratives ainsi que de données d'une enquête auprès de 2107 clients des régions Sud et Nord-Est du Brésil, les résultats ne montrent aucun impact significatif sur les revenus, la création d'emplois, l'accès au crédit et la structuration des entreprises,

\section{Rafael Goldszmidt}

rafael.goldszmidt@fgv.br

1 Brazilian School of Public and Business Administration, Getulio Vargas Foundation, Rua Jornalista Orlando Dantas 30, Rio de Janeiro 22231-010, Brazil

2 School of Management, RMIT University, Melbourne, Australia

3 University of Lugano, Lugano, Switzerland

4 Center for Microfinance and Financial Inclusion Studies, Sao Paulo School of Business Administration, Getulio Vargas Foundation, Rio de Janeiro, Brazil

5 GRADE, Lima, Peru 
avec une exception au sein des municipalités les plus pauvres du Nord-Est, où le microcrédit a montré des effets positifs.

JEL Classification $\mathrm{O} 12 \cdot \mathrm{O} 16 \cdot \mathrm{G} 21$

\section{Introduction}

Existing studies of the impact of microcredit have mostly failed to show that microcredit has a transformative effect on poor peoples' lives, in particular with regards to income generation, consumption, and employment generation. Most of these studies have evaluated microcredit impacts by means of randomized controlled trials (RCTs), usually in cooperation with a local lender and for a relatively small region of the country that the lender is active in (e.g. Karlan and Zinman 2011; Angelucci et al. 2013; Attanasio et al. 2015; Crépon et al. 2015; Banerjee et al. 2015; Tarozzi et al. 2015). ${ }^{1}$ Besides these RCTs, there are also several meta-studies that come to overall similar conclusions (Stewart et al. 2012; Chliova et al. 2015; Gopalaswamy et al. 2016; Duvendack and Mader 2020). Criticism of the microcredit model in general can be found in recent work by Bateman (2019). The lack of success of microcredit is discussed in Bateman and Maclean (2017). Critical views on financial inclusion to which our study connects to on a broader level are, e.g., provided in Duvendack and Mader (2020) and Mader (2018).

Our study comes to an overall similar conclusion as these cited studies. Two features, which represent the contribution of this study, set the present study apart from others, however. First, we measure microcredit impacts for 16 different microfinance institutions (MFIs), while most studies typically focused solely on a single MFI. Furthermore, our study is able to gauge microcredit impacts for two vast macroregions in the country, instead of a single small region of the country as in most microcredit impact evaluations where the rollout of a new product is considered (notable exceptions are, e.g., the studies by Kaboski and Townsend (2012), for Thailand, and Augsburg et al. 2015, for Bosnia and Herzegovina). This should increase the external validity of our results. Furthermore, it is the first large-scale evaluation of the impact of microcredit in Brazil-arguably the most important economy in Latin and South America-using primary data.

Recent literature suggests that microcredit can have significant short-term, but insignificant long-term effects (e.g. Buchenrieder et al. 2019; Hossain et al. 2019). We therefore compare old (or veteran) recipients of microcredit to (relatively) new recipients to measure the impact of microcredit in Brazil. We are aware of the empirical drawbacks that our approach entails (see Karlan 2001). We try to circumvent these problems by matching veteran to new clients on several dimensions. ${ }^{2}$ Veteran

\footnotetext{
1 A notable exception is the study by Bruhn and Love (2014) who find positive effects of introducing a microfinance-like product on income and labor market outcomes.

2 Floro and Swain (2012) and Cintina and Love (2017) also use propensity score matching to evaluate the impact of microfinance on the individual level.
} 
and new beneficiaries were matched exactly on municipality, MFI that extended the loan, economic sector (agriculture, industry and services), type of loan (individual or group contract), as well as age bracket, sex, marital status, and credit score. We combined the matching procedure with OLS regressions (following Ho et al. 2007) to measure the difference in the outcomes between veteran and new clients as the microcredit impacts.

The primary data collection for the impact evaluation occurred between September 2016 and January 2017, in cooperation with BNDES, Brazil's largest development bank. BNDES is owned fully by the Brazilian government and at the time the study was conducted had an active microcredit portfolio of around 230 million US dollars. BNDES does not grant loans directly to microentrepreneurs as it does not operate a branch network; it provides funds to MFIs which channel the funds to the clients according to their internal standards and operations.

We collected administrative data from 38 MFIs that received funds from BNDES — which amounts to 84\% of all MFIs using BNDES funds in 2016 - and identified approximately 10,700 potential survey participants. ${ }^{3}$ We then applied a one-time in-depth survey to 2107 clients of the MFIs covering several important dimensions for impact evaluation: income generation, access to credit, employment generation, and business formalization. Within each family of outcomes, we used several dependent variables to evaluate microcredit impacts in Brazil. We estimated and present microcredit impacts separately for the Northeast of Brazil and for the South. The reason is that while both areas are poor by Western standards, the Northeast of Brazil is much poorer than the South and is also substantively different in several other dimensions (e.g., culture, infrastructure), hence, mixing individuals from both regions in the impact evaluation would deliver a distorted picture of the effects. ${ }^{4}$ We also tested for heterogeneous treatment effects within each macroregion comparing municipalities with different levels of human development. The final sample consisted of 1601 survey participants, 1070 from the Northeast and 531 from the South.

Our results are in line with most of the existing microcredit impact studies, as we did not find transformative effects of microcredit across a large family of impact dimensions and outcome variables. Individuals in the treatment group, on average, do not seem to have done better than individuals in the control group. In line with this overall finding, Duvendack and Mader (2020) provide a systematic overview of 32 meta-studies in which they come the conclusion that microcredit impacts do not seem to have transformative effects on poor people's lives. The only treatment effect we find in our study is among businesses located in areas with lower levels of human development in the Northeast of the country. In this subset of the participants, old beneficiaries have higher sales and less months in which the revenues were lower than costs compared to the control group. This should lead to higher profits for these

\footnotetext{
3 The final sample includes clients from less than 38 MFIs because some of the MFIs only had very few clients that received loans disbursed from BNDES funds.

4 We did not include individuals from other regions in Brazil because there are very few MFIs that use BNDES funds for their microcredit activities.
} 
businesses, but the coefficient in the profit regression, while being relatively large economically, is not significant.

We do, however, find several interesting patterns in the data that have potentially important policy implications. The most robust of these patterns is that women have lower income than men, create less jobs (albeit this effect being economically small), and have less access to credit. These regularities hold, however, only in the Northeast and not in the South of Brazil, which might be an indication of gender discrimination in the economically less developed Northeast. Another interesting pattern we observe is that formalized businesses have higher revenues and income, but this may very well be a result of reverse causality. The data also show that businesses in municipalities with lower levels of development in the Northeast have higher credit scores than the businesses in municipalities with higher levels. This might be an indication of different client targeting practices by MFIs. In relatively richer municipalities, MFIs may be extending loans also to riskier clients, while in the poorer municipalities they only target clients with a good credit track record. Overall, our results call for more or more efficient women empowerment, for instance through specific public policies targeted at women, in particular in the poorest areas of the country.

\section{Institutional Background}

The Brazilian Development Bank (henceforth BNDES-Banco Nacional de Desenvolvimento Econômico e Social) initially entered the microcredit market in 1996. At that time, the bank funded MFIs and in the following years established a technical cooperation agreement with the Interamerican Development Bank. BNDES's microcredit activities expanded in 2005 when a temporary program was created (Programa de Microcrédito do BNDES) and later transformed in 2014 into a permanent line of credit (Produto BNDES Microcrédito, PBM). This product does not directly fund microentrepreneurs, but instead grants loans to MFIs (such as development or commercial banks, credit cooperatives, local development agencies and non-governmental agencies). These MFIs offer microloans according to the PNMPO guidelines, which encompass loans for small entrepreneurs with annual income of up to BRL 120,000 (USD 34,285) channeled through MFIs that have loan officers in direct contact with the entrepreneurs.

BNDES started to operate with funds of 250 million Reais (71.4 million US dollars) and reached one billion Reais (286 million US dollars) in 2013. Among BNDES' active clients in 2016 there were 45 MFIs. Most of BNDES' funded loans are disbursed in the Northeast of Brazil (77\%) where Crediamigo is the main client ( $90 \%$ of Northeast contracts), followed by the South of Brazil (15\%), where the loans are distributed in between credit cooperatives (26\%), commercial banks (14\%) and local development agencies (60\%). MFIs in the Southeast and Central-West regions only account for a minor share of all the funds that BNDES distributes. This is the major reason why beneficiaries from those regions are not included in our sample. 
The MFIs in our sample also rely on funding other than the BNDES funding. For instance, $58 \%$ of them use customer deposits and $49 \%$ use funding from other state banks. Nevertheless, in the vast majority of cases, BNDES funding is the most important funding source. Furthermore, the MFIs included in our sample make up around $70 \%$ of the microcredit market in Brazil (Gonzalez et al. 2017). This suggests that our findings are representative for the Brazilian microcredit market.

\section{Materials and Methods}

\section{Design of the Impact Evaluation}

As an RCT was not feasible in our case due to operational and logistical reasons, we implemented a comparison between early and late loans. The "treatment" in our study, therefore really means receiving a loan "earlier" as opposed to "later". In this paper, we refer interchangeably to new clients and late loans, which will compose the "control" group, and to early loans and old/veteran clients, who are the "treatment" group. This approach allowed us to observe microcredit effects of a program implemented on a large nation-wide scale and in a wide variety of MFIs, obtaining treatment estimates under general equilibrium and avoiding site-selection bias.

Two obvious threats to the validity of this comparison come from selection and attrition (Karlan 2001). Attrition is particularly a problem in our design as it is harder to locate early beneficiaries than late beneficiaries. We dealt with this potential problem by making an effort to supplement the MFI's information on beneficiaries using data purchased from credit bureaus. This way, even if a beneficiary interrupted her relationship with the microcredit provider, we were usually able to update contact information.

With respect to selection, all individuals in our study have eventually applied for and received a microfinance loan. By definition, this implies that any self-selection process that might be at work is necessarily weaker than what would be obtained in a comparison between other types of non-randomly defined groups of beneficiaries and non-beneficiaries of a microloan (Coleman 2006). It is still possible that early beneficiaries are qualitatively different from late-beneficiaries due to some form of residual self-selection or even changes in the selection criteria employed by the microfinance agents. We sought to minimize this problem by matching early and late beneficiaries on many important pretreatment observed characteristics.

A third threat to inference comes from the fact that the operational difficulties in obtaining and standardizing the administrative data from all MFIs forced us to field the survey a few months after the recent beneficiaries had been awarded loans. This happened because not all MFIs complied with the data request, therefore delaying the survey. The consequence is that by the time in which we fielded the survey, on average, eight months had passed since the granting of the loans to late-beneficiaries. The difference between the control and treated groups, therefore, consists of having either received a first loan 20 months before, or eight months before the interview. Given this, our study in fact compares the short-term to the long-term effects of microcredit in Brazil. This does, however, not imply that we are comparing start-ups 
versus established businesses as business in the control as well as in the treatment group have similar business ages as we point out below.

\section{Sample Construction}

We were authorized to request data about all microcredit loans that were funded totally or partially by PBM since its roll out in 2014. For each such loan, we obtain loan specific information (amount, interest rate, number of installments, if first loan or not), client specific information (such as age, sex and contact information), as well as business-specific information (such as sector of activity and revenue, when available). We identified 45 MFIs participating in PBM, 38 of which complied with the data information request in time to be included in the study (encompassing more than $90 \%$ of PBM's portfolio).

The total of 123,977 first time microcredit loans granted by MFIs funded by BNDES was initially pruned by limiting eligible participants to those defined as veteran beneficiaries (who obtained their first loan from PBM in the first quarter of 2016) and new beneficiaries (those that obtained their first loan in the first quarter of 2017). ${ }^{5}$ This left us with 32,494 loans. We then matched early beneficiaries to late beneficiaries to determine the subset of the population that was eligible to be included in the study. Old and new beneficiaries were matched exactly on municipality, MFI, economic sector (agriculture, industry and services), type (individual or group loan), as well as age bracket, sex, marital status and month in which the loan was obtained (January, February or March).

This procedure generated a matched subset of 24,906 loans. Due to operational concerns, we further limited this subset to municipalities in which there were at least 30 early and 30 late beneficiaries (in the Northeast) and 15 early and 15 late beneficiaries (in the South), which generated a sampling subset of 10,733 loans (or $43 \%$ of the matched subset). The sampling's subset geographic dispersion reflects that of the matched subset.

From the sampling subset, we first randomly selected 64 municipalities, ensuring that the two macro-regions of the country that receive more than $90 \%$ of the funds from BNDES for microcredit and all levels of development, were represented. We stratified the municipalities in the sample by level of development (measured by the Human Development Index of each municipality-HDI-M) within each geographic region. Thus, we assured a balanced sample of the poorer and richer municipalities within the South and Northeast regions. We then acquired credit scores at the time of the loan take-up and six months after for all individuals in the subset, and further refined the matches of early to late beneficiaries using this information. ${ }^{6}$

The credit scores were related to the individual entrepreneur and not to the business as most of the financial transactions of these businesses are performed with the entrepreneur's individual tax identification number. Furthermore, this allowed

\footnotetext{
5 The number of beneficiaries in 2014 and previous years was too small to serve as the baseline.

${ }^{6}$ It was prohibitively costly to obtain credit scores for the full population of cases.
} 
us to match formal and informal entrepreneurs alike. We obtained the credit scores from one of Brazil's largest credit bureaus so they were available regardless of their use by the MFIs in the credit decision process. More than $98 \%$ of the entrepreneurs had enough information in the bureau to have a credit score. ${ }^{7}$ This was a fundamental measure for matching as it is objective, could be retrieved retrospectively, and was also obtainable for the veteran clients. After the inclusion of the credit score we performed a Mahanalobis-distance matching and paired each veteran client to its nearest neighbor without replacement. We then sampled observations from these treatment-control pairs. A final sample of 3223 loans was selected from this refined matched sampling subset. This number included possible replacements to achieve an expected number of 2800 interviews.

We were able to complete 2107 interviews because 854 businesses were not located, 243 refused to answer and 19 responses were invalidated by quality control concerns. The sample analyzed was further reduced to 1602 after we excluded individuals who reported having previously received a microcredit loan from some other MFI, and those who reported never having had a business. The final sample included loans from 16 different MFIs.

It is important to point out that not all MFIs were able to deliver the required information about their clients as quickly as initially planned. Consequently, we compare microcredit clients that had a credit contract with an MFI outstanding for on average 8.51 months versus veteran clients that had a credit contract outstanding for on average 20.81 months. To assess whether this resulted in distributional differences between the treatment and control group individuals, we compared new clients with below the median time of credit contract and above the median time. We did not find any significant differences in this comparison.

\section{Descriptive Statistics}

Table 1 displays descriptive statistics of the sample, separately for the Northeast and the South. The tables show several notable differences between regions. Beneficiaries in the South are on average 5 years older than those from the Northeast. Furthermore, microcredit beneficiaries from the South are more often male, more often married, and somewhat better educated on average. They run slightly older businesses, mainly in the service sector (restricted to services not including the trade of physical assets such as barber shops), while most microbusinesses in the Northeast are from the commerce sector (activities related to trading goods such as groceries). Beneficiaries from the South also have higher credit scores, which should translate into less risky loans. The most notable difference is the formalization status: $61 \%$ of all microbusinesses in the South were formalized before receiving the first microloan, most often in the form of an individual microentrepreneur, while the number in

\footnotetext{
7 In Brazil, credit bureaus register data from a broad array of events such as payment of service bills (e.g. electricity) or installments of direct financing by shops, as well as any request for credit. Thus, even if the entrepreneur had no contact with financial institutions, she could have a credit score.
} 
Table 1 Descriptive statistics

\begin{tabular}{|c|c|c|c|c|}
\hline & \multicolumn{2}{|c|}{ Northeast } & \multicolumn{2}{|l|}{ South } \\
\hline & Mean & SD & Mean & SD \\
\hline \multicolumn{5}{|l|}{ Demographics } \\
\hline Number of people in household & 3.84 & 1.60 & 3.36 & 1.31 \\
\hline Beneficiary age (years) & 33.60 & 11.43 & 38.74 & 11.74 \\
\hline Female & 0.68 & 0.47 & 0.57 & 0.50 \\
\hline \multicolumn{5}{|l|}{ Marital status } \\
\hline Single & 0.33 & 0.47 & 0.20 & 0.40 \\
\hline Married & 0.61 & 0.49 & 0.72 & 0.45 \\
\hline Widow, divorced or separated & 0.06 & 0.24 & 0.08 & 0.26 \\
\hline \multicolumn{5}{|l|}{ Education } \\
\hline No formal degree & 0.08 & 0.27 & 0.05 & 0.23 \\
\hline Primary school & 0.43 & 0.50 & 0.41 & 0.49 \\
\hline High school or more & 0.49 & 0.50 & 0.54 & 0.50 \\
\hline Business age (years) & 4.49 & 3.77 & 5.77 & 4.30 \\
\hline \multicolumn{5}{|l|}{ Business sector } \\
\hline Industry & 0.02 & 0.14 & 0.06 & 0.24 \\
\hline Commerce & 0.76 & 0.43 & 0.35 & 0.48 \\
\hline Service & 0.14 & 0.35 & 0.53 & 0.50 \\
\hline Farming & 0.05 & 0.22 & 0.01 & 0.11 \\
\hline Mixed & 0.03 & 0.16 & 0.04 & 0.20 \\
\hline Credit score before first loan & 448 & 205 & 494 & 215 \\
\hline Formalized before first loan (according to MFI) & 0.07 & 0.26 & 0.61 & 0.49 \\
\hline \multicolumn{5}{|l|}{ Outcomes } \\
\hline \multicolumn{5}{|l|}{ Income } \\
\hline Total household income (in Reais) & 2059 & 2045 & 4614 & 4334 \\
\hline Sales last month (in Reais) & 1636 & 2769 & 4120 & 5115 \\
\hline Profit last month (in Reais) & 620 & 1344 & 1688 & 2933 \\
\hline Months with income smaller than expenses in last six & 1.77 & 1.15 & 1.80 & 1.41 \\
\hline \multicolumn{5}{|l|}{ Employment generation } \\
\hline Number of employees in household & 0.32 & 0.64 & 0.27 & 0.56 \\
\hline Number of employees out of household & 0.19 & 0.60 & 0.44 & 1.07 \\
\hline No employees in household & 0.74 & 0.44 & 0.77 & 0.42 \\
\hline No employees out of household & 0.88 & 0.32 & 0.79 & 0.41 \\
\hline \multicolumn{5}{|l|}{ Access to credit } \\
\hline Number of accessible sources of credit & 1.57 & 1.87 & 3.78 & 2.65 \\
\hline Had credit request refused in last 6 months & 0.02 & 0.13 & 0.05 & 0.22 \\
\hline No access to credit & 0.38 & 0.49 & 0.16 & 0.37 \\
\hline \multicolumn{5}{|l|}{ Formalization } \\
\hline Formalized & 0.10 & 0.30 & 0.77 & 0.42 \\
\hline Formalized as MEI & 0.09 & 0.28 & 0.60 & 0.49 \\
\hline Intent to formalize & 0.37 & 0.48 & 0.42 & 0.50 \\
\hline \multicolumn{5}{|l|}{ Data collection } \\
\hline Time from first loan to interview for control group & 8.66 & 32.18 & 8.19 & 36.24 \\
\hline Time from first loan to interview for treated group & 20.88 & 34.02 & 20.64 & 36.68 \\
\hline
\end{tabular}

This table shows descriptive sample statistics $S D$ standard deviation 
the Northeast is a mere 7\%, indicating that $93 \%$ of all beneficiaries in the Northeast owned informal businesses when they received their first microloan.

The table also displays notable differences between the regions for the outcome variables. Beneficiaries in the South are much richer than their counterparts in the Northeast and they also run larger businesses. Finally, beneficiaries from the South also have a much better access to credit than those in the Northeast, which may be explained by their better education, the higher share of formalized businesses and their higher wealth.

\section{Main Specification}

To eschew the potential effects of differential attrition between veteran and new clients, for the main analysis we conducted a second round of matching. Just as in the sample construction phase, we matched early loan survey respondents (treatment group) to late loan survey respondents (control group), requiring exact matches for municipality and microcredit provider. As the survey generated much more finely grained information on each interviewee, we were able to expand the set of variables to match on to include age, sex, educational level, marital status, sector of activity, credit score prior to the loan, age of business, month of loan-between January and March-and pre-loan formalization status.

However, due to the much smaller number of individuals available for matching, instead of exact matching, we performed nearest neighbor matching with replacement and up to three-to-one control-to-treatment ratio on the other matching variables. Given that the sample had already been drawn from a matched subset of all loans the propensity scores are distributed very similarly across treated and control loans (see Fig. 1).

We estimated the effect of the treatment (defined as early vis-à-vis late loan) on each outcome of interest by estimating regressions of the sort:

$$
Y_{i}=\beta_{0}+\beta_{1} \text { Treat }_{i}+\delta X_{i}+\theta_{i}+\pi+\omega+\varepsilon_{i}
$$

where $Y_{i}$ is the outcome of interest for individual $i$ and Treat is an indicator that takes on the value of one if individuals were early beneficiaries and zero otherwise. The estimate of the treatment effect is the coefficient $\beta_{1}$, which captures the difference in means between the treatment and control groups, conditional on the other variables. $\mathrm{X}$ is a vector of individual level control variables common to all models. It includes an indicator for sex, individual's age and age of business (both measured at the time of the loan), marital status, the individual's credit score one month before the first loan, and a dummy indicator that takes on the value of one if the business was formalized before taking the loan. We include as covariates all the variables used in the matching to increase power. The specification also includes sector of activity $(\theta)$, municipality-MFI fixed effects $(\pi)$, and interviewer fixed effects $(\omega)$. 


\section{Panel A: Northeast}

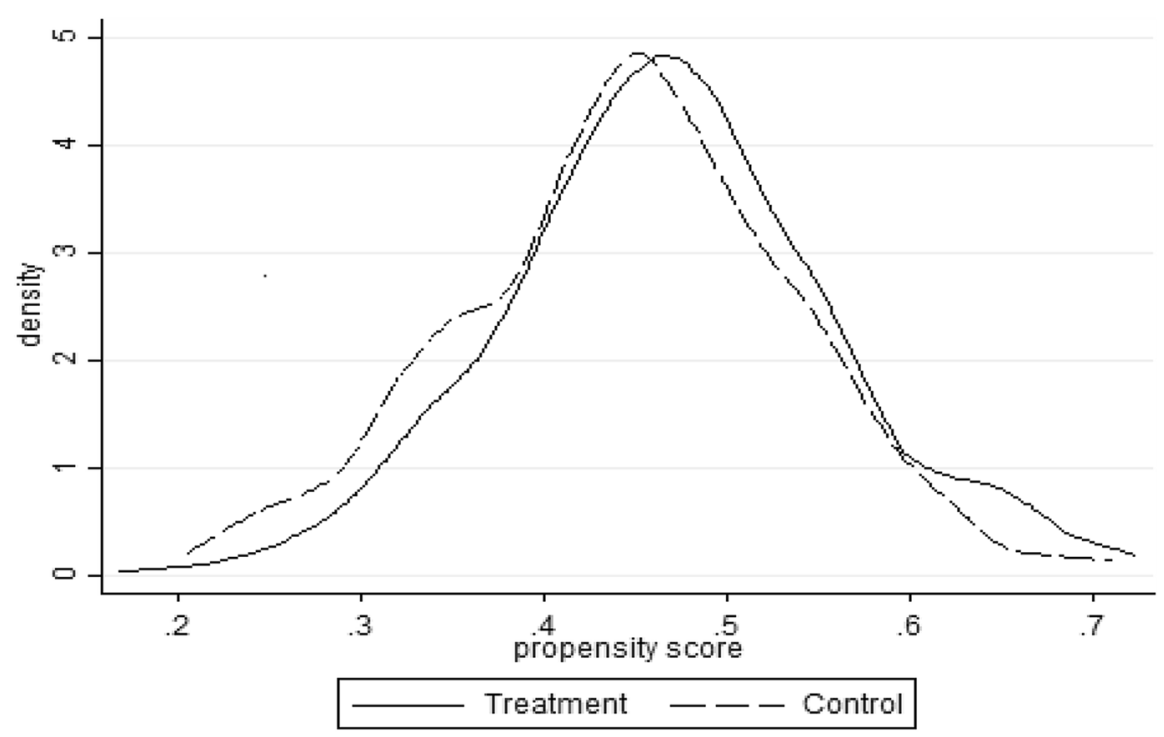

\section{Panel B: South}

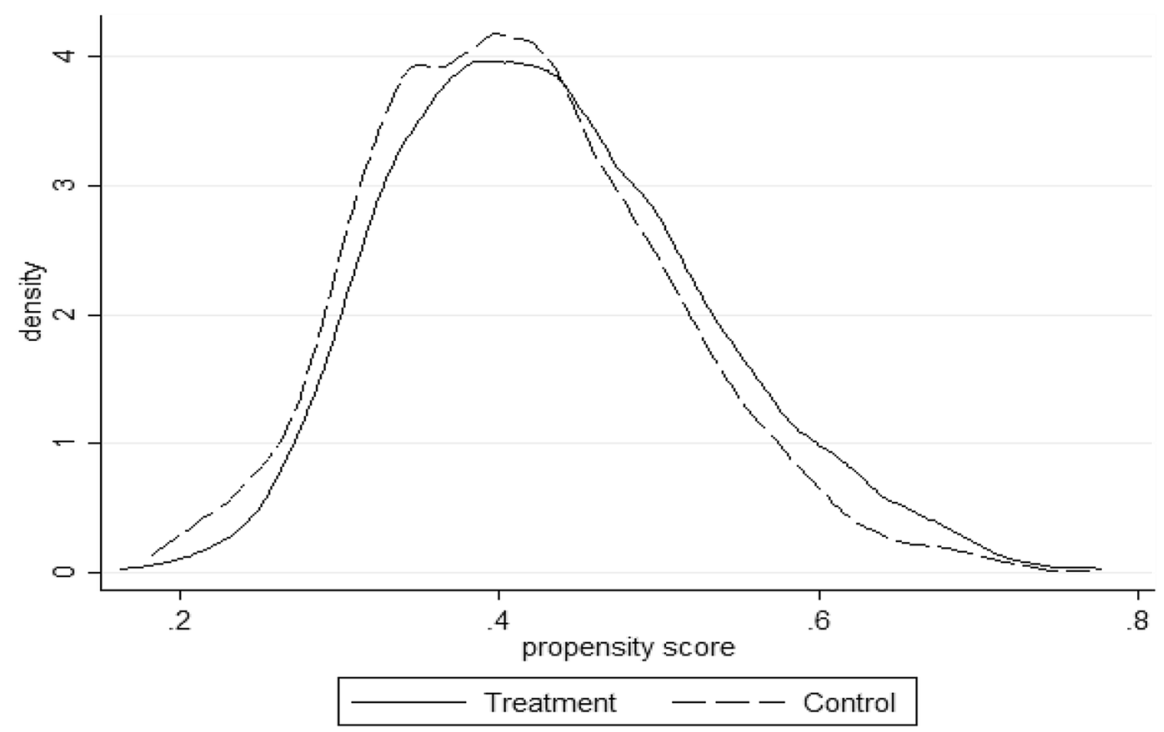

Fig. 1 Distributions of propensity scores by treatment condition and region 
All models were estimated by OLS with the weights generated by the matching procedure, as recommended in Ho et al. (2007).

\section{Results}

\section{Results for Income}

The most important impact dimension is, arguably, income generation. The fundamental idea of microcredit was to give poor entrepreneurs small business loans so that they can make investments and grow their businesses. Eventually, this should result in higher incomes and improved living conditions. Yet, most impact evaluations did not find strong effects of microcredit on poor peoples' income or business profits (e.g., Karlan and Zinman 2011; Angelucci et al. 2013; Crépon et al. 2015). One of the difficulties in impact evaluations of microcredit is income measurement as this relies on self-reporting of the microcredit beneficiaries (de Mel et al. 2009). For instance, in our case we computed business income in two ways. First, we asked the beneficiaries to self-report their monthly profit in the last month. ${ }^{8}$ We then asked them about their revenues and their costs in the last month and computed the difference as profits. In the vast majority of cases, both profit figures were different.

We report the results using the computed profit figure in the regressions, but the findings hold considering the self-reported profit as well. Further to business profits, we use revenues in the last month, total household income, income from other sources than the business, and months in the last six months in which the revenues were below the costs as outcome variables. Finally, we also use a variable that combines all five outcomes into an index as sometimes individual outcomes are not significant because of low statistical power (Kling et al. 2007). The index was computed as the factor score from a one-dimensional factor analysis. All regressions are estimated using OLS and controls and fixed effects were included as indicated in the table. Results for the Northeast are displayed in Panel A of Table 2, and for the South in Panel B.

For the Northeast, the treatment dummy is not significant for any of the outcomes of interest and similar results are observed in the South. These results suggest that treated individuals did not do better than control individuals with regard to income generation. This result is broadly in line with the results of the meta-studies of Chliova et al. (2015) with a global focus and Gopalaswamy et al. (2016) covering South Asia.

One interesting result is that female business owners earn significantly less than male business owners, independent of the treatment in the Northeast. The effect is highly significant and economically large. For instance, the average male business owner has sales of BRL 2174 (USD 621) and female owners of BRL 1390 (USD

\footnotetext{
${ }^{8}$ We only asked for business profits, expenses and sales in the last month because we believe it may be too difficult to remember business profits for months further in the past as poor business owners usually do not have any written records.
} 


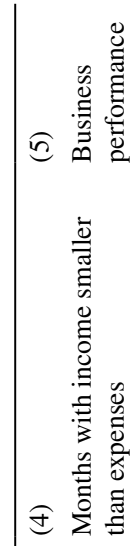

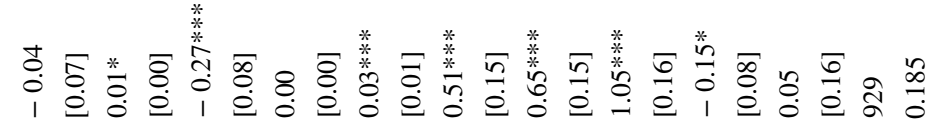

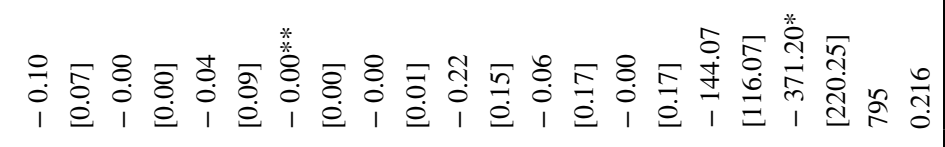

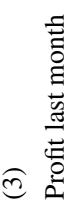

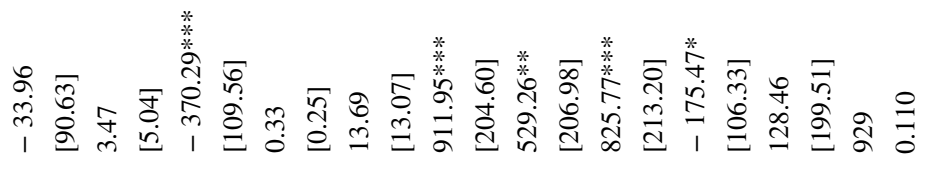

حิ

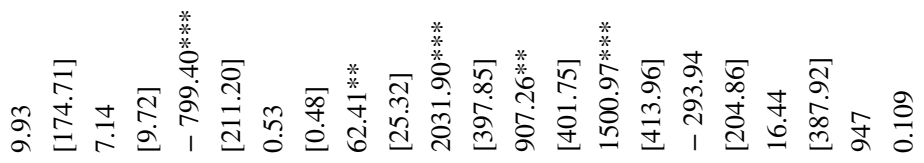

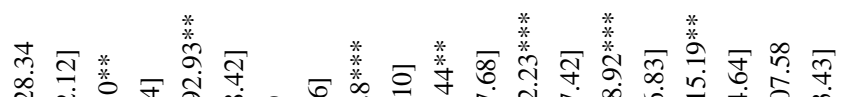

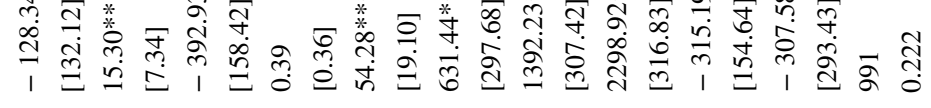

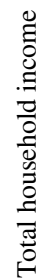

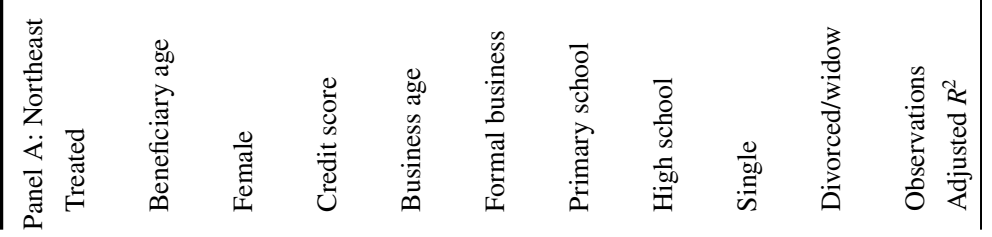


|c

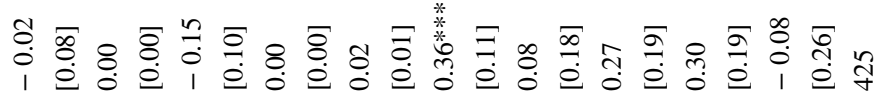

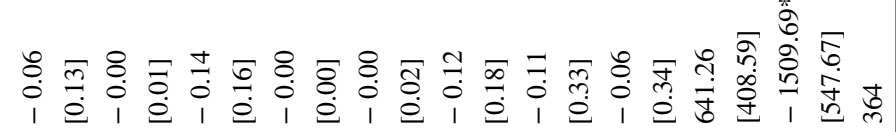

余泀

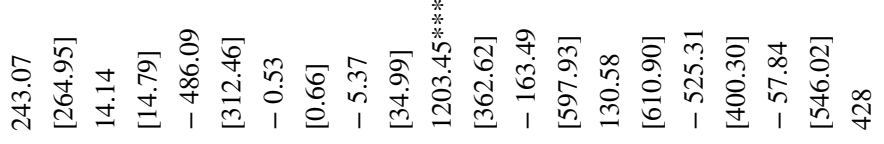




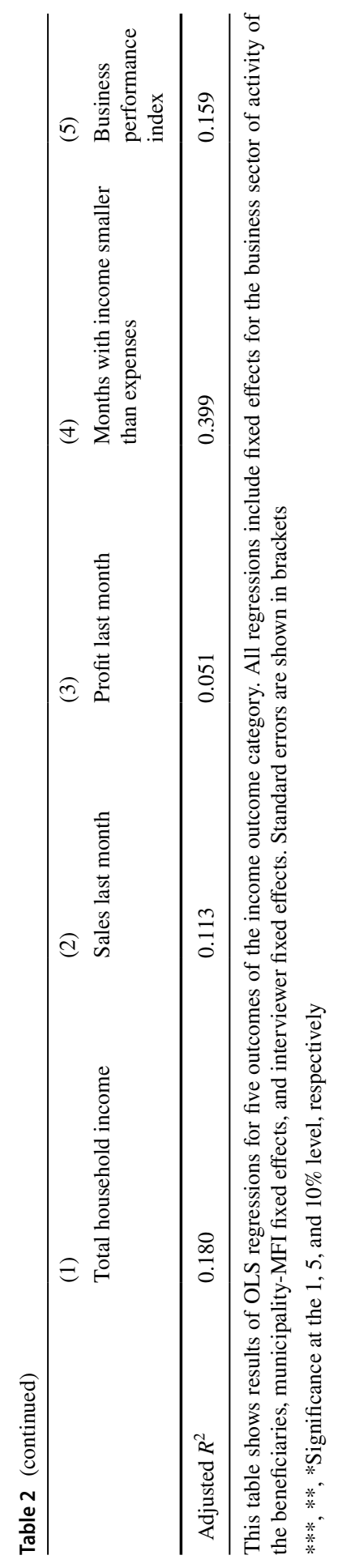


397). Even though the coefficient sign and size is similar in the South, it is not significant. One explanation for this result is that discrimination against women may be more prevalent in the poorer Northeast than in the South. Additionally, education seems to play a relevant role in the Northeast with positive and significant coefficients for the variables representing primary and high school (compared to the no formal degree reference category) in most observed outcomes. Surprisingly, there is no effect of education in the South, except for a significant effect of high school degree (vs. no formal education) on sales.

Finally, owners of formalized businesses have higher sales and bigger business profits, both in the Northeast and the South. This result has to be interpreted with caution, though, as it could be a consequence of reverse causality whereby more profitable business owners were more likely to formalize their businesses. All results equally hold if we use regression models with several additional control variables such as loan size or whether the beneficiary had received another loan. For sake of brevity, we only present the parsimonious models for income and all other outcome variables. The additional results are available in the supplementary material to this article.

\section{Results for Employment Generation}

The second impact category we investigate is employment generation. While we did not find any direct impact of microcredit on poor peoples' income, it might be that they create opportunities for others by creating new jobs. It could also be that by creating jobs, there might be a reduction in the number of family members working in the business which, for instance, might increase schooling. To exploit this possibility, we measure impact across four outcomes: workers from the own household (i.e., family members), workers outside the own household, the number of businesses without workers from the own family, and the number of businesses with non-family member workers. As an aggregated index we used the total number of employees adding those living in and out of the household. The results for the Northeast are displayed in Panel A of Table 3 and for the South in Panel B.

We do not find any significant results in either macro-region for any of the outcomes. Coefficients are not significant and economically very small. The results in Panel A show that female business owners in the Northeast seem to generate less employment as they employ less non-family member workers and run more businesses without any workers, regardless of whether they are family or non-family members. We do not see the same effect for female business owners from the South, in which female-owned businesses in fact have more employees in the household. On the other hand, business owners from the South that have a formal business seem to have more workers both from within and outside the own family. As in the case of income generation, we are cautious in interpreting this result as it could be subject to reverse causality. Overall, treated individuals did not fare any different from control individuals. In their meta-study with a global focus, Stewart et al. (2012) reach the same conclusion, that is, microcredit does not lead to job creation. 


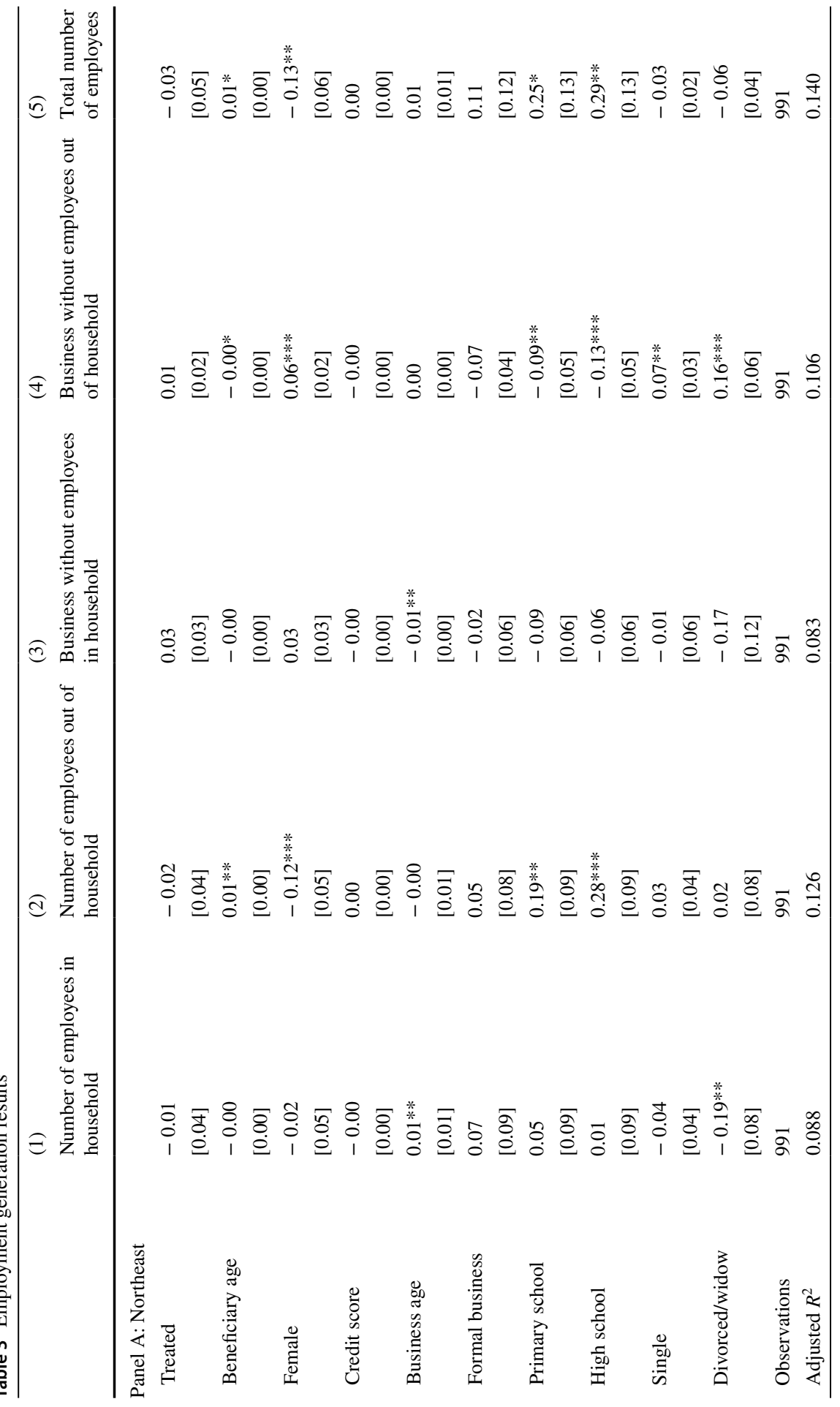




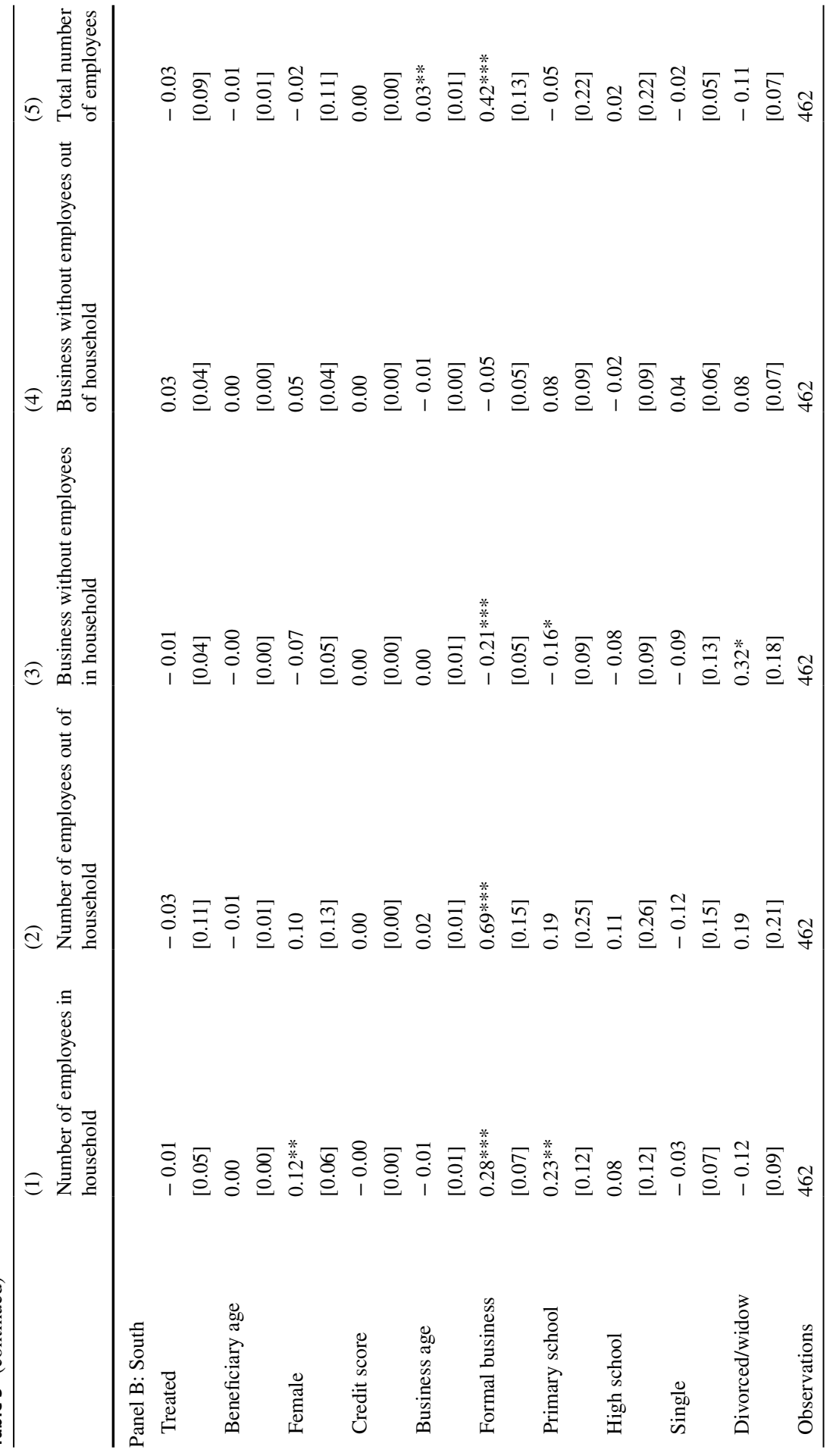

s. 


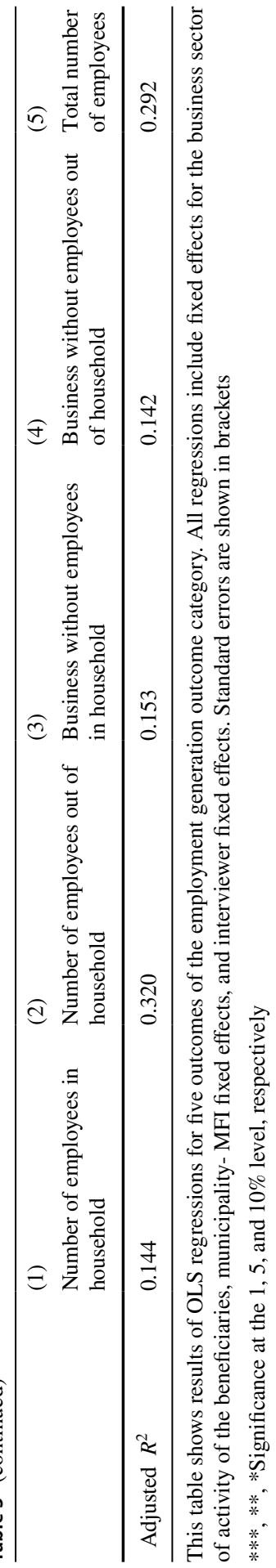


Table 4 Access to credit results

(1)

Number of sources

of accessible

sources of credit
(2)

Had credit request refused in last

6 months

\begin{tabular}{|c|c|c|c|c|}
\hline \multicolumn{5}{|l|}{ Panel A: Northeast } \\
\hline \multirow[t]{2}{*}{ Treated } & -0.14 & -0.00 & 0.04 & -0.08 \\
\hline & {$[0.10]$} & {$[0.01]$} & {$[0.03]$} & {$[0.06]$} \\
\hline \multirow[t]{2}{*}{ Beneficiary age } & $0.01 * *$ & 0.00 & -0.00 & $0.01 * *$ \\
\hline & {$[0.01]$} & {$[0.00]$} & {$[0.00]$} & {$[0.00]$} \\
\hline \multirow[t]{2}{*}{ Female } & $-0.52 * * *$ & 0.01 & $0.08 * *$ & $-0.28 * * *$ \\
\hline & {$[0.12]$} & {$[0.01]$} & {$[0.03]$} & {$[0.07]$} \\
\hline \multirow[t]{2}{*}{ Credit score } & 0.00 & -0.00 & $-0.00 * *$ & 0.00 \\
\hline & {$[0.00]$} & {$[0.00]$} & {$[0.00]$} & {$[0.00]$} \\
\hline \multirow[t]{2}{*}{ Business age } & -0.00 & $0.00 * *$ & -0.00 & 0.00 \\
\hline & {$[0.01]$} & {$[0.00]$} & {$[0.00]$} & {$[0.01]$} \\
\hline \multirow[t]{2}{*}{ Formal business } & $0.40 *$ & 0.02 & -0.10 & $0.24 *$ \\
\hline & {$[0.23]$} & {$[0.02]$} & {$[0.06]$} & {$[0.13]$} \\
\hline \multirow[t]{2}{*}{ Primary school } & $0.85^{* * *}$ & -0.02 & $-0.17 * *$ & $0.49 * * *$ \\
\hline & {$[0.24]$} & {$[0.02]$} & {$[0.07]$} & {$[0.13]$} \\
\hline \multirow[t]{2}{*}{ High school } & $1.30 * * *$ & -0.02 & $-0.29 * * *$ & $0.74 * * *$ \\
\hline & {$[0.25]$} & {$[0.02]$} & {$[0.07]$} & {$[0.13]$} \\
\hline \multirow[t]{2}{*}{ Single } & -0.06 & 0.00 & 0.03 & -0.04 \\
\hline & {$[0.12]$} & {$[0.01]$} & {$[0.03]$} & {$[0.06]$} \\
\hline \multirow[t]{2}{*}{ Divorced/widow } & 0.31 & $0.04^{* *}$ & -0.09 & 0.16 \\
\hline & {$[0.23]$} & {$[0.02]$} & {$[0.06]$} & {$[0.12]$} \\
\hline Observations & 991 & 991 & 991 & 991 \\
\hline Adjusted $R^{2}$ & 0.303 & 0.029 & 0.202 & 0.294 \\
\hline \multicolumn{5}{|l|}{ Panel B: South } \\
\hline \multirow[t]{2}{*}{ Treated } & -0.20 & 0.03 & 0.02 & -0.08 \\
\hline & {$[0.20]$} & {$[0.02]$} & {$[0.03]$} & {$[0.08]$} \\
\hline \multirow[t]{2}{*}{ Beneficiary age } & 0.00 & 0.00 & 0.00 & 0.00 \\
\hline & {$[0.01]$} & {$[0.00]$} & {$[0.00]$} & {$[0.00]$} \\
\hline \multirow[t]{2}{*}{ Female } & -0.11 & -0.03 & 0.03 & -0.05 \\
\hline & {$[0.23]$} & {$[0.03]$} & {$[0.04]$} & {$[0.09]$} \\
\hline \multirow[t]{2}{*}{ Credit score } & 0.00 & $-0.00 * *$ & -0.00 & 0.00 \\
\hline & {$[0.00]$} & {$[0.00]$} & {$[0.00]$} & {$[0.00]$} \\
\hline \multirow[t]{2}{*}{ Business age } & 0.03 & -0.00 & -0.00 & 0.01 \\
\hline & {$[0.03]$} & {$[0.00]$} & {$[0.00]$} & {$[0.01]$} \\
\hline \multirow[t]{2}{*}{ Formal business } & $0.82 * * *$ & 0.02 & $-0.09 *$ & $0.30 * * *$ \\
\hline & {$[0.27]$} & {$[0.03]$} & {$[0.05]$} & {$[0.11]$} \\
\hline \multirow[t]{2}{*}{ Primary school } & 0.54 & 0.01 & -0.02 & 0.16 \\
\hline & {$[0.46]$} & {$[0.05]$} & {$[0.08]$} & {$[0.18]$} \\
\hline \multirow[t]{2}{*}{ High school } & 0.77 & 0.01 & -0.03 & 0.26 \\
\hline & {$[0.47]$} & {$[0.05]$} & {$[0.08]$} & {$[0.18]$} \\
\hline
\end{tabular}

(3)

(4)

No access to credit Credit access index Credit access index

P

Panel A: Northeast 
Table 4 (continued)

(1)

Number of sources of accessible sources of credit
(2)

Had credit request refused in last 6 months

\begin{tabular}{lllll}
\hline Single & 0.23 & 0.03 & 0.00 & 0.12 \\
& {$[0.29]$} & {$[0.03]$} & {$[0.05]$} & {$[0.11]$} \\
Divorced/widow & -0.17 & 0.05 & 0.00 & -0.05 \\
& {$[0.39]$} & {$[0.04]$} & {$[0.07]$} & {$[0.15]$} \\
Observations & 459 & 459 & 459 & 459 \\
Adjusted $R^{2}$ & 0.416 & 0.095 & 0.197 & 0.394 \\
\hline
\end{tabular}

This table shows results of OLS regressions for four outcomes of the access to credit outcome category. All regressions include fixed effects for the business sector of activity of the beneficiaries, municipalityMFI fixed effects, and interviewer fixed effects. Standard errors are shown in brackets

$* * *, * *, *$ Significance at the 1,5 , and $10 \%$ level, respectively

\section{Results for Access to Credit}

To measure the impact of microcredit on access to credit, we created three different outcomes as well as an overall index based on nine indicators of access to credit by credit source (e.g. bank, credit cooperative). Besides asking the survey participants about the number of sources of credit they think they have access to (Table 4, column 1), we also asked them whether they had any loan application rejected in the last six months (column 2) and whether they think they have no access to any source of credit at all (column 3). Finally, in column (4), we report the results for the index that combines the answer to three questions.

As before, we do not find any treatment effects for individuals from the Northeast and for the South. Some baseline patterns, however, are quite interesting. In the Northeast (Panel A) female microentrepreneurs seem to have access to fewer sources of finance, and the number of sources of credit increases with education. In both cases, results are significant for the number of sources of credit, the absence of any source of credit, and for the combined index. The results for gender are in line with the effects we documented before: female business owners in the Northeast earn less, they create less jobs and they have more difficult access to credit. The fact that education has no effect in the South might reflect a higher education premium linked to lower overall levels of education in the Northeast.

Formalization (observed ex-ante) is another baseline pattern that seems to have a consistent effect, and in this case the effect is present not only in the Northeast but also and particularly in the South. It is probably the case that formal businesses are also better structured and business owners more prepared to successfully seek out credit, but in this case, we suppose that formalization serves more as signal of creditworthiness than an actual cause of it. Given this result and the fact that the Federal Government has sponsored since 2009 the "Individual Microentrepreneur Program", which is a major policy initiative to formalize microentrepreneurs, more research is needed on the direct effects of formalization 
on business performance and access to credit (for work on this, see, for instance, Lenz and Valdivia, 2017).

\section{Results for Business Formalization}

One striking result of the survey was that around $90 \%$ of survey participants in the Northeast were running informal businesses while this figure is reduced to $24 \%$ in the South. This difference may be related to the design of the MFIs microcredit offer which tends to be geared towards formalized entrepreneurs in the South more than in the Northeast. Formalizing a business can have positive effects for the business owners. For instance, they can hire workers that are looking for a formal job, it makes it easier to apply for a loan from the formal financial sector, and the business owner is granted the right to get access to the public pension system. Of course, there are also negative aspects such as formal workers are more expensive, formal businesses have to pay taxes and are subject to more bureaucracy. ${ }^{9}$ It could very well be that these disadvantages outweigh the positive aspects of formalizing a business. In fact, many of the owners of informal businesses replied that they would not know why they should formalize their business when asked during the survey.

Our interest here was whether there were significantly more formal businesses among the treated business owners. We used three outcomes to analyze this question. ${ }^{10}$ Column (1) of Table 5 shows whether treated individuals have more often formalized businesses, column (2) shows whether there are more businesses formalized as individual microbusinesses (MEI) among treated business owners (this information was obtained from secondary sources, alongside formalization date), and column (3) shows the intention to formalize the business. As before, none of the treatment effects are significant, but some baseline patterns in the Northeast are worth noting. Female microentrepreneurs, once again, underperform relative to their male counterparts, with fewer formalizing and, though not significantly, intending to formalize. Education seems to have a strong effect on intention to formalize, but this effect is only observable for the highest education group.

\section{Heterogeneous Treatment Effects by Municipality Human Development Index}

Finally, we analyze whether the wealth of the municipality the entrepreneurs live in influences the impacts of microcredit. The underlying idea is that microcredit may impact poor business owners differently if they are surrounded by predominantly poor individuals or by relatively richer individuals. For instance, it could be the case that in poorer municipalities cheaper labor is available and that it is easier to hire

\footnotetext{
9 The simplest way to formalize a business in Brazil is to register it as a MEI, which stands for individual microentrepreneur. The annual revenues of these businesses must not exceed BRL 60,000 (USD 17,143 ) and they have to pay a monthly flat tax of BRL 55 (USD 16). While the monthly tax payment is a trivial amount by Western standards, it may still be prohibitively high for many microbusinesses.

${ }^{10}$ In these regressions we do not control for whether a business is formalized or not unlike in previous regressions.
} 
Table 5 Formalization results

(1)

Formalized

Panel A: Northeast

Treated

Beneficiary age

Credit score

Business age

Primary school

High school

Single

Divorced/widow

Observations

Adjusted $R^{2}$

Panel B: South

Treated

Beneficiary age

Female

Credit score

Business age

Primary school

Single

Divorced/widow

Observations

Adjusted $R^{2}$$$
0.00
$$$$
\text { [0.02] }
$$$$
0.00
$$$$
\text { [0.00] }
$$$$
-0.08 * * *
$$$$
\text { [0.02] }
$$$$
-0.00
$$$$
\text { [0.00] }
$$$$
0.01^{* * *}
$$$$
\text { [0.00] }
$$$$
0.03
$$$$
\text { [0.04] }
$$$$
0.06
$$$$
\text { [0.04] }
$$$$
-0.04 *
$$$$
\text { [0.02] }
$$$$
-0.04
$$$$
\text { [0.04] }
$$$$
732
$$

0.081

$-0.00$

[0.09]

0.00

[0.00]

$-0.22 * *$

[0.11]

$-0.00$

[0.00]

$-0.01$

[0.01]

0.24

[0.18]

0.31

[0.18]

$-0.11$

[0.16]

$-0.24$

[0.19]

112

0.413
(2)

(3)

Formalized as MEI

Intent to formalize

$-0.03$

[0.03]

$-0.00$

[0.00]

$-0.06$

[0.04]

$-0.00 * *$

[0.00]

$-0.01$

[0.00]

$0.14^{*}$

[0.08]

0.20 **

[0.08]

$0.10^{* * *}$

[0.04]

$-0.05$

[0.08]

697

0.201

$-0.003$

$-0.11$

[0.19]

$-0.01$

[0.01]

0.05

[0.19]

0.00

[0.00]

0.03

[0.02]

$-0.40$

[0.34]

$-0.55$

[0.35]

$-0.07$

[0.30]

$-0.02$

[0.33]

79

0.006 
Table 5 (continued)

This table shows results of OLS regressions for three outcomes of the business formalization outcome category. All regressions include fixed effects for the business sector of activity of the beneficiaries, municipality-MFI fixed effects, and interviewer fixed effects. Standard errors are shown in brackets $* * *, * *, *$ Significance at the 1,5 , and $10 \%$ level, respectively

Table 6 Heterogeneous treatment effects (HDI)

\begin{tabular}{|c|c|c|c|c|c|}
\hline & (1) & (2) & (3) & (4) & (5) \\
\hline & $\begin{array}{l}\text { Total } \\
\text { household } \\
\text { income }\end{array}$ & Sales last month & Profit last month & $\begin{array}{l}\text { Months with } \\
\text { income smaller } \\
\text { than expenses }\end{array}$ & $\begin{array}{l}\text { Business } \\
\text { perform. } \\
\text { Index }\end{array}$ \\
\hline \multicolumn{6}{|c|}{ Panel A: Northeast } \\
\hline Treated & $\begin{array}{l}-13.56 \\
{[177.17]}\end{array}$ & $\begin{array}{l}-248.36 \\
{[233.05]}\end{array}$ & $\begin{array}{l}-61.85 \\
{[121.39]}\end{array}$ & $\begin{array}{l}0.01 \\
{[0.10]}\end{array}$ & $\begin{array}{l}-0.03 \\
{[0.09]}\end{array}$ \\
\hline Low HDI- M & $\begin{array}{l}81.40 \\
{[681.85]}\end{array}$ & $\begin{array}{l}-317.11 \\
{[883.17]}\end{array}$ & $\begin{array}{l}69.08 \\
{[454.85]}\end{array}$ & $\begin{array}{l}0.30 \\
{[0.37]}\end{array}$ & $\begin{array}{l}0.01 \\
{[0.34]}\end{array}$ \\
\hline \multirow[t]{2}{*}{$\begin{array}{l}\text { Low HDI- } \\
\text { M*Treated }\end{array}$} & -260.09 & $591.85^{*}$ & 63.41 & $-0.24^{*}$ & -0.02 \\
\hline & {$[267.47]$} & [353.87] & {$[183.60]$} & {$[0.15]$} & {$[0.14]$} \\
\hline Baseline & 2266.00 & 1789.93 & 630.01 & 1.73 & 0.07 \\
\hline Observations & 991 & 947 & 929 & 795 & 929 \\
\hline Adjusted $R^{2}$ & 0.222 & 0.111 & 0.110 & 0.218 & 0.183 \\
\hline \multicolumn{6}{|l|}{ Panel B: South } \\
\hline Treated & $\begin{array}{l}-231.98 \\
{[462.85]}\end{array}$ & $\begin{array}{l}-409.89 \\
{[617.95]}\end{array}$ & $\begin{array}{l}112.71 \\
{[370.20]}\end{array}$ & $\begin{array}{l}-0.02 \\
{[0.17]}\end{array}$ & $\begin{array}{l}-0.10 \\
{[0.11]}\end{array}$ \\
\hline Low HDI-M & $\begin{array}{l}-2449.85 \\
{[4082.06]}\end{array}$ & $\begin{array}{l}-3746.27 \\
{[5343.87]}\end{array}$ & $\begin{array}{l}-2972.50 \\
{[3134.41]}\end{array}$ & $\begin{array}{l}1.56 \\
{[1.64]}\end{array}$ & $\begin{array}{l}-0.85 \\
{[0.97]}\end{array}$ \\
\hline \multirow[t]{2}{*}{$\begin{array}{l}\text { Low HDI- } \\
\text { M*Treated }\end{array}$} & 694.69 & 552.47 & 97.20 & -0.04 & 0.17 \\
\hline & [686.79] & [927.18] & [549.19] & {$[0.26]$} & {$[0.17]$} \\
\hline Baseline & 5126.64 & 4239.83 & 1459.38 & 1.99 & 1.45 \\
\hline Observations & 459 & 433 & 425 & 362 & 425 \\
\hline Adjusted $R^{2}$ & 0.180 & 0.119 & 0.053 & 0.408 & 0.157 \\
\hline
\end{tabular}

This table shows results of OLS regressions for five outcomes of the income outcome category. All regressions include fixed effects for the business sector of activity of the beneficiaries, municipality-MFI fixed effects, and interviewer fixed effects. The regressions also include all control variables used in the other regressions. Their coefficients are omitted to save space. Baseline indicates the average value for new clients in low HDI-M regions. Standard errors are shown in brackets

*Significance at the $10 \%$ level

workers and grow the business. On the other hand, in relatively less poor areas, it may be that potential consumers have more purchasing power and it is easier for poor business owners to stimulate demand for their products after making use of the microloans by investing in the business. ${ }^{11}$

\footnotetext{
11 One may imagine a beauty salon that after making an investment becomes more attractive for customers because of an improvement of how the beauty salon looks to customers. While this may matter
} 
We measure wealth of the municipality through the HDI-M in which higher values indicate more developed (and richer) municipalities. To explore whether the wealth of the business surroundings influence the impact of microcredit, we interact the treatment dummy with an indicator for whether the municipality belongs to the lower half of the distribution of HDI-M in the sample of the region. The results for income are displayed in Table 6.

For two outcomes of interest, we found a significant treatment effect in the poorer half of the municipalities. Whereas the treated individuals in high development areas reported lower sales in comparison to the control group, those in the less developed areas reported higher sales. The difference in the treatment effects between the two groups of municipalities was almost BRL 600 (USD 171). This is a large economic effect, given that the average sales for beneficiaries in the control condition was approximately BRL 1800 (USD 514) in less developed municipalities.

Moreover, the negative and significant coefficient of the interaction term in column (4) of Panel A suggests that treated individuals from the relatively poorer municipalities experienced $1 / 4$ fewer months (in the last six) in which their revenues were below the costs. Together with the higher sales, this should result in higher profits. However, the interaction term in column (3) in Panel A, while being economically relevant, is not statistically significant. We do not see a similar pattern for beneficiaries from the South in Panel B. We conducted further analysis using an interaction term with the treatment dummy and the school education of the business owners, but these interaction terms were neither significant in the low-HDI areas in the Northeast nor in the South. These results are available in the supplementary material to this article.

Further descriptive analysis reveals that both treated beneficiaries from municipalities with HDIs above the median have on average much higher credit scores (around 25\% higher) than treated individuals from municipalities with HDIs below the median. We interpret this as different client targeting by MFIs. It seems that MFIs in relatively richer municipalities also give loans to individuals with higher credit risk (maybe because the low-risk customers have access to other sources of financing), while in the relatively poorer municipalities the MFIs predominantly target low-risk business owners. We cannot tell from our data and analyses whether this is a strategic choice of the MFIs or whether this is due to different degrees of market saturation in municipalities with high and low HDIs. However, we view this to be an interesting result that warrants further analyses as it may inform us about under which circumstances and how microcredit can create positive effects.

Footnote 11 (continued)

less for poor consumers, relatively richer consumers may find it more attractive to demand the salon's services. 


\section{Conclusion}

This paper presents results from a large-scale, observational microcredit impact evaluation in Brazil. The impact evaluation was conducted in cooperation with BNDES, Brazil's largest fully government-owned development bank. We interviewed 2107 beneficiaries of microcredit who received their first microloan in the first quarter of 2016 or in the first quarter of 2017. We then compared differences in short-term versus long-term outcomes for 27 outcome variables across four outcome categories between treated and control clients. We use a PSM approach to achieve comparability between treated and control beneficiaries and interpret any resulting differences between both groups as the impact of microcredit. We estimate and present treatment effects separately for the richer South and for the Northeast of Brazil.

We do not find any significant microcredit impacts for income, employment generation, access to credit, and business formalization in the Northeast or in the South. As our sample resembles the overall distribution of microcredit activity in Brazil, our findings suggest that there are no general transformative impacts of microcredit in Brazil. This result is in line with most of the existing RCTs and also with the results of meta-studies about the impact of microcredit. It is also in line with many of the critical works on the overall potential of microcredit to fight poverty.

Further analysis shows that beneficiaries in the Northeast who live in less developed municipalities have higher sales and less months in which costs are higher than revenues, suggesting a positive impact of microcredit on business success in these regions. The data also suggest that MFIs target riskier clients in municipalities with HDIs below the sample median and that this correlates with the impact of microcredit on business success.

One consistent finding for beneficiaries from the Northeast is that female owners of microbusinesses fare much worse in several dimensions than their male counterparts. They have less income, run smaller microbusinesses and face more credit constraints. Furthermore, they more often run informal businesses and show a lower subjective wellbeing than male owners of microbusinesses. These findings may be a consequence of gender discrimination in the poorer Northeast and call for public policies that are specifically targeted at the economic empowerment of women.

Acknowledgements We thank Eduardo Ferreira for helpful comments and suggestions. We also thank Renata Carneiro for excellent research assistance. We further thank BNDES' Department of Evaluation and Effectiveness Promotion for discussions and for making the data available.

Funding Open Access funding provided by Università della Svizzera italiana.

\section{Declarations}

Conflict of interest This research is based on the results of a consulting project. It was undertaken by a subset of the authors, which were hired and paid by BNDES for the execution of the consulting project. After the successful conclusion and with the explicit permission of BNDES, several additional coauthors were invited to participate in the preparation of this research manuscript. At no point did BNDES interfere in the preparation of the research manuscript or asked the final author team to drop or add analyses or change any 
of the interpretations. The authors also declare that no permission was needed by BNDES before journal submission of this manuscript. Hence, there are no conflicts of interest to be reported.

Open Access This article is licensed under a Creative Commons Attribution 4.0 International License, which permits use, sharing, adaptation, distribution and reproduction in any medium or format, as long as you give appropriate credit to the original author(s) and the source, provide a link to the Creative Commons licence, and indicate if changes were made. The images or other third party material in this article are included in the article's Creative Commons licence, unless indicated otherwise in a credit line to the material. If material is not included in the article's Creative Commons licence and your intended use is not permitted by statutory regulation or exceeds the permitted use, you will need to obtain permission directly from the copyright holder. To view a copy of this licence, visit http://creativecommons.org/licen ses/by/4.0/.

\section{References}

Angelucci, M., D. Karlan, and J. Zinman. 2013. Win Some Lose Some? Evidence from a Randomized Microcredit Program Placement Experiment by Compartamos Banco. Working Paper.

Attanasio, O., B. Augsburg, R. De Haas, E. Fitzsimons, and H. Harmgart. 2015. The Impacts of Microfinance: Evidence from Joint-Liability Lending in Mongolia. American Economic Journal: Applied Economics 7 (1): 90-122.

Augsburg, B., R. De Haas, H. Harmgart, and C. Meghir. 2015. The Impacts of Microcredit: Evidence from Bosnia and Herzegovina. American Economic Journal: Applied Economics 7 (1): 183-203.

Banerjee, A., E. Duflo, R. Glennerster, and C. Kinnan. 2015. The Miracle of Microfinance? Evidence from a Randomized Evaluation. American Economic Journal: Applied Economics 7 (1): 22-53.

Bateman, M. 2019. Impacts of the Microcredit Model: Does theory reflect actual practice. In The Rise and Fall of Global Microcredit: Development, Debt and Disillusion, ed. Bateman et al London: Routledge, 42-68.

Bateman, M., and K. Maclean. 2017. Seduced and Betrayed: Exposing the Contemporary Microfinance Phenomenon. University of New Mexico Press and the School for Advanced Research Press, 376.

Buchenrieder, G., J. Nguefo Gnilachi, and E.O. Benjamin. 2019. Poverty Alleviation Through Microcredit in Sub-Saharan Africa Revisited: New Evidence from a Cameroonian Village Bank, the Mutuelle Communautaire de Croissance. Agricultural Finance Review 79 (3): 386-407.

Bruhn, M., and I. Love. 2014. The Real Impact of Improved Access to Finance: Evidence from Mexico. Journal of Finance 69 (3): 1347-1376.

Cintina, I., and I. Love. 2017. Re-evaluating Microfinance: Evidence from Propensity Score Matching. World Bank Economic Review, 1-21.

Chliova, M., J. Brinckman, and N. Rosenbusch. 2015. Is Microcredit a Blessing for the Poor? A Metaanalysis Examining Development Outcomes and Contextual Considerations. Journal of Business Venturing 30 (3): 467-487.

Coleman, B.E. 2006. Microfinance in North East Thailand: Who Benefits and how Much? World Development 34 (9): 1612-1638.

Crépon, B., F. Devoto, E. Duflo, and W. Parienté. 2015. Estimating the Impact of Microcredit on Those Who Take It Up: Evidence from a Randomized Experiment in Morocco. American Economic Journal: Applied Economics 7 (1): 125-150.

de Mel, S., D.J. McKenzie, and C. Woodruff. 2009. Measuring Microenterprise Profits: Must we Ask how the Sausage is Made? Journal of Development Economics 88 (1): 19-31.

Duvendack, M., and P. Mader. 2020. Impact of Financial Inclusion in Low- and Middle-Income Countries: A Systematic Review of Reviews. Journal of Economic Surveys 34 (3): 594-629.

Floro, M., and R.B. Swain. 2012. Assessing the Effect of Microfinance on Vulnerability and Poverty among Low Income Households. The Journal of Development Studies 48 (5): 605-618.

Gonzalez, L., L. Porto, and E.H. Diniz. 2017. Microcrédito produtivo no Brasil: Histórico recente e condicionantes de desenvolvi-mento. Cadernos Gestão Pública e Cida-Dania 22 (72): 184-204.

Gopalaswamy, A.K., Babu, M.S., and U. Dash. 2016. Systematic Review of Quantitative Evidence on the Impact of Microfinance on the Poor in South Asia. London: EPPI-Centre, Social Science Research Unit, UCL Institute of Education, University College London, 267. 
Ho, D.E., K. Imai, G. King, and E.A. Stuart. 2007. Matching as Nonparametric Preprocessing for Reducing Model Dependence in Parametric Causal Inference. Political Analysis 15 (3): 199-236.

Hossain, M., M.A. Malek, Md.A. Hossain, Md.H. Reza, and Md.S. Ahmed. 2019. Agricultural Microcredit for Tenant Farmers: Evidence from a Field Experiment in Bangladesh. American Journal of Agricultural Economics 101 (3): 692-709.

Kaboski, J.P., and R.M. Townsend. 2012. The Impact of Credit on Village Economies. American Economic Journal: Applied Economics 4 (2): 98-133.

Karlan, D.S. 2001. Microfinance Impact Assessments: The Perils of Using New Members as a Control Group. Journal of Microfinance/ESR Review 3 (2): 75-85.

Karlan, D., and J. Zinman. 2011. Microcredit in Theory and Practice: Using Randomized Credit Scoring for Impact Evaluation. Science 332: 1200138.

Kling, J.R., J.B. Liebman, and L.F. Katz. 2007. Experimental Analysis of Neighborhood Effects. Econometrica 75 (1): 83-119.

Lenz, A.-K., and M. Valdivia. 2017. Budging Through Nudging into Formalization. Working paper.

Mader, P. 2018. Contesting Financial Inclusion. Development and Change 49 (2): 461-483.

Stewart, R., C. vanRooyen, M. Korth, A. Chereni, N. Rebelo Da Silva, and T. deWet. 2012. Do Microcredit, Micro-savings and Micro-leasing Serve as Effective Financial Inclusion Interventions Enabling Poor People, and Especially Women, to Engage in Meaningful Economic Opportunities in Low- and Middle- Income Countries? A Systematic Review of the Evidence. Technical report, EPPI-Centre, Social Science Research Unit, University of London.

Tarozzi, A., J. Desai, and K. Johnson. 2015. The Impacts of Microcredit: Evidence from Ethiopia. American Economic Journal: Applied Economics 7 (1): 54-89.

Publisher's Note Springer Nature remains neutral with regard to jurisdictional claims in published maps and institutional affiliations. 